\title{
栄養士養成課程学生の目測能力および食意識変化
}

堀内理恵 $*$ ·大浦麻衣子** ·藤井久美子 $* * *$ 北脇涼子*

谷野永和* · 高橋 徹****

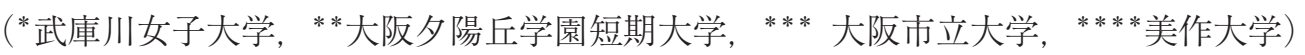

\section{Changes in Abilities of Visual Estimation for the Weight of Foodstuffs and Food Consciousness of Dietician College Students}
Rie Horiuchi *, Maiko Ooura**, Kumiko Fujii***, Ryoko Kitawaki*, Saeko Yokomizo *, Norikazu Tanino * and Toru Takahashi

*Mukogawa Women's University, 6-46, Ikebirakicho, Nishinomiya City, Hyogo, 663-8558

** Osaka Yuhigaokagakuen Junior College, 7-72, Ikutamateramachi, Tennoji-ku, Osaka City, Osaka, $543-0073$

*** Osaka City University, 3-3-138, Sugimoto, Sumiyoshi-ku, Osaka City, Osaka, 558-8585 **** Mimasaka University, 50, Kitazonocho, Tsuyama City, Okayama, 708-8511

$$
\begin{aligned}
& \text { *テ663-8558 兵庫県西宮市池開町 6-46 } \\
& \text { ** }=543-0073 \text { 大阪府大阪市天王寺区生玉寺町 7-72 } \\
& \text { *** }=558-8585 \text { 大阪府大阪市住吉区杉本 3-3-138 } \\
& * * * * 708-8511 \text { 岡山県津山市北園町 } 50
\end{aligned}
$$

Estimating the weights of foodstuffs and concentrations of salt and the sucrose in foods on the market is important for planning menus and carrying out a diet survey as a dietician. Whether female college students contemplating a career as a dietitian can change the visual estimation ability for the weights or concentrations and food consciousness by learning a special subject after a certain period of time was studied. What was additionally needed in the training was discussed in order to provide a more effective method of education.

The estimating capability tended to be improved after the training. It was presumed that it occurs due to from practical training or lectures of the special subject.

As a result of the survey, food consciousness and food behavior were significantly improved. It was proved that improving the estimation capability needed not only practical training to cook using a scale, but also execution to eat regular meals or maintain a balanced diet.

To acquire enhanced dietician skills, they should be provided a scientific basis for eating regular meals or keeping a balance and adopt healthy habits.

Moreover, it was proved that the students have to be first highly-motivated.

緒言

栄養士養成課程教育の場においては，現場栄養士とし て即戦力となる人材育成に努めているが, 将来, 栄養士 から管理栄養士へのスキルアップを円滑に進めることを 指向した総合的な授業内容を包含することも必要である。
食品重量を目測で把握することや，市販食品の塩分濃 度・糖分に対する認識は, 栄養士にとって献立作成時や 食事調査等において基礎となる重要な能力である。しか し食品重量の見積もり能力についての報告 ${ }^{1) ~ 4) ~}$ が数は少ない。既報 ${ }^{5)}$ より学生は, ほとんどの食品重量 の目測を実測值よりも低く見積もった。また, 塩分含有 
量は高く見積もり，糖分含有量では低く見積もる傾向に あった。

本研究では，一定期間専門科目の教育を受けた後，栄 養士を志す学生の食品重量の見積もり能力, 市販食品の 塩分含有量, 糖分含有量に対する認識力および食意識が どのように変化したか，さらに教育効果を向上させるた めに必要な項目について検討し若干の知見を得たので報 告する。

\section{調査方法}

\section{1. 対象者および調査時期}

本調査では，大阪府下にある短期大学食物栄養専攻の 2 年生 179 人（栄養士養成課程女子学生）を対象とし, 給食管理実習時間に，平成18，19年 4 月（オリエンテー ション初日）抽び12月（大量調理実習終了後のまとめ をする期間)，授業の一環として実施した。記名はさせ たが，調査結果は成績には関係ないことを伝えた上で実 施した。なお，H18年およびH19年の実習内容はほぼ同 じであった。

\section{2. 調査項目}

\section{1) 食品重量の目測・塩分含有量調査・糖分含有量 調査}

食品重量の目測については黒川 ${ }^{11}$ の方法に従い，日常
摂取する機会の多いと考えられる食品26品目, 調理食品 7 品目と, 乾物 6 品目については, 戻す前と戻したもの を取り上げ，皿の上にのせた実物を展示し，重量を目測 で記入させた。また，塩分調査および糖分調査は各々 5 品目取り上げ含有量を重量で推測して記入させた（表 1 )。 4 月と 12 月の実物の展示は重量をそろえて実施し, 調査 後の結果について学生に開示した。

解答で得られた数值を「見積もり值」とし，実測值と の誤差を次の式で算出し，目測誤差率として表した ${ }^{12}{ }^{2)}$ 。

目測誤差率 $=\mid$ 見積もり值 - 実測值 $\mid \div$ 実測值 $\times 100$

目測誤差率10\%以内を適正に見積もられた正解域群と し，10\%以上を正解域圈外群とした。

\section{2 ）食意識・食生活行動調査}

食意識・食生活行動についての質問項目は国民健康 · 栄養調査を参考にして作成し, 食品重量の目測・塩分含 有量調査・糖分含有量と同時に, 自己式質問用紙を配布 して行った。

\section{3. 統計処理}

SPSS 13.0を用い各項目間でクロス集計をし， $\chi^{2}$ 検 定を行い，クラメール連関係数を求めた。一定期間前後 の比較はウイルコクソン検定を行った。質問項目につい て，一定期間前後で因子分析（主因子法）を行い，プロ マックス回転を行った。

表 1 対象食品

\begin{tabular}{|c|c|c|c|c|c|}
\hline 番号 & & 番号 & & 番号 & \\
\hline 1 & 白飯 & 10 & 大根 & 19 & スライスハム \\
\hline 2 & 食パン & 11 & ピーマン & 20 & ウィンナー \\
\hline 3 & ゆでうどん & 12 & ほうれんそう & 21 & 鶏卵 \\
\hline 4 & ビゃがいも & 13 & バナナ & 22 & ヨーグルト \\
\hline & (メークイン) & 14 & りんご & 23 & チーズ \\
\hline 5 & 豆腐（木綿） & 15 & レモン & 24 & ショートケーキ \\
\hline 6 & 油揚げ & 16 & さば & 25 & シュークリーム \\
\hline 7 & たまねぎ & 17 & 牛ステーキ & 26 & クッキー \\
\hline 8 & キャベッ & 18 & 鶏モモ肉 & & \\
\hline 9 & レタス & & & & \\
\hline
\end{tabular}

\begin{tabular}{|c|c|}
\hline 番号 & 重量見積もり（調理食品） \\
\hline 27 & おにぎり \\
\hline 28 & キャベツ（せんぎり） \\
\hline 29 & キャベツ（炒め） \\
\hline 30 & 大根おろし \\
\hline 31 & ほうれんそう（ゆで） \\
\hline 32 & 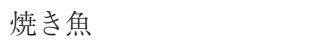 \\
\hline 33 & トンカツ \\
\hline 番号 & 塩分含有量見積もり食品 \\
\hline 46 & ケチャップ \\
\hline 47 & インスタントラーメン \\
\hline 48 & ロースハム \\
\hline 49 & チーズ \\
\hline 50 & インスタントみそ汁 \\
\hline
\end{tabular}

\begin{tabular}{|c|c|c|c|}
\hline \multicolumn{4}{|c|}{ 重量見積もり食品（乾物） } \\
\hline 番号 & 乾燥 & 番号 & 戻したもの \\
\hline 34 & そうめん & 40 & そうめん \\
\hline 35 & 高野豆腐 & 41 & 高野豆腐 \\
\hline 36 & ワカメ & 42 & ワカメ \\
\hline 37 & ひじき & 43 & ひじき \\
\hline 38 & しいたけ & 44 & しいたけ \\
\hline \multirow[t]{7}{*}{39} & 春雨 & 45 & 春雨 \\
\hline & 番号 & 糖分含有量見 & 責もり食品 \\
\hline & 51 & ポカリスウェ & ・卜 \\
\hline & 52 & 缶コーヒー & \\
\hline & 53 & クッキー & \\
\hline & 54 & 100\%果汁ジ & ース \\
\hline & 55 & 大福もち & \\
\hline
\end{tabular}


日本食生活学会誌 Vol.20 No.3（2009）

表 2 対象者の基本属性

\begin{tabular}{clrr}
\hline 項目 & & 人数 & $(\%)$ \\
\hline \hline 居住地区 & 大阪 & 145 & 82.9 \\
& 兵庫 & 3 & 1.7 \\
& 奈良 & 17 & 9.7 \\
& 京都 & 1 & 0.6 \\
& 和歌山 & 5 & 2.9 \\
& その他 & 4 & 2.3 \\
出身地区 & 大阪 & 137 & 78.3 \\
& 兵庫 & 2 & 1.1 \\
& 奈良 & 15 & 8.6 \\
& 京都 & 1 & 0.6 \\
& 和歌山 & 8 & 4.6 \\
& その他 & 12 & 6.9 \\
居住形態 & 1 世代 & 11 & 6.3 \\
& 2 世代 & 132 & 75.9 \\
& 3世代 & 31 & 17.9 \\
\hline
\end{tabular}

表 3 A 2 回目に值が改善された目測誤差率

\begin{tabular}{|c|c|c|c|}
\hline 食品名 & （4月） & （12月） & $\begin{array}{l}\text { WilcoxonO符 } \\
\text { 号つき順位検定 }\end{array}$ \\
\hline 白飯 & $49.27 \pm 20.42$ & $29.47 \pm 20.92$ & $* * *$ \\
\hline 食パン & $36.35 \pm 1.91$ & $18.50 \pm 1.66$ & $* * *$ \\
\hline ゆでうどん & $51.79 \pm 1.66$ & $32.88 \pm 1.68$ & $* * *$ \\
\hline じゃがいも(メークィン) & $57.01 \pm 1.64$ & $41.82 \pm 1.62$ & $* * *$ \\
\hline 豆腐（木綿） & $56.88 \pm 1.93$ & $37.33 \pm 1.97$ & $* * *$ \\
\hline 油揚げ & $45.72 \pm 3.04$ & $33.33 \pm 2.07$ & $* *$ \\
\hline たまねぎ & $52.85 \pm 1.90$ & $36.97 \pm 1.72$ & $* * *$ \\
\hline キャベツ & $65.00 \pm 1.83$ & $57.30 \pm 1.87$ & $* *$ \\
\hline レタス & $61.78 \pm 1.88$ & $52.17 \pm 2.64$ & $* * *$ \\
\hline 大根 ～～～～～～ & $60.71 \pm 1.82$ & $50.52 \pm 2.17$ & $* * *$ \\
\hline ほうれんそう & $48.71 \pm 1.96$ & $42.56 \pm 2.77$ & $* *$ \\
\hline ピーマン & $46.60 \pm 2.18$ & $30.01 \pm 2.32$ & $* * *$ \\
\hline りんご & $60.36 \pm 1.74$ & $36.81 \pm 1.83$ & $* * *$ \\
\hline レモン & $55.84 \pm 1.74$ & $37.06 \pm 1.56$ & $* * *$ \\
\hline ウインナー & $52.01 \pm 2.01$ & $40.57 \pm 2.69$ & $* * *$ \\
\hline 鶏卵 ～～～～～～ & $15.67 \pm 2.11$ & $7.43 \pm 1.00$ & $* * *$ \\
\hline $\begin{array}{l}\text { ヨーグルト } \\
\text { (調理食品) }\end{array}$ & $42.56 \pm 1.94$ & $34.75 \pm 3.32$ & $* * *$ \\
\hline キャベツ（炒め） & $57.60 \pm 2.20$ & $46.04 \pm 3.22$ & $* * *$ \\
\hline $\begin{array}{l}\text { 大根おろし } \\
\text { (乾物・乾燥) }\end{array}$ & $52.24 \pm 3.18$ & $48.08 \pm 4.69$ & $*$ \\
\hline ワカメ & $207.82 \pm 16.05$ & $165.20 \pm 14.79$ & $* *$ \\
\hline 春雨 & $68.37 \pm 5.13$ & $51.08 \pm 2.83$ & $* *$ \\
\hline $\begin{array}{l}\text { ひじき } \\
\text { (乾物·戻したもの) }\end{array}$ & $161.66 \pm 12.14$ & $106.53 \pm 9.40$ & $* * *$ \\
\hline $\begin{array}{l}\text { そうめん } \\
\text { (塩分) }\end{array}$ & $48.08 \pm 2.13$ & $40.83 \pm 2.26$ & $* *$ \\
\hline インスタントラーメン & $137.18 \pm 29.34$ & $67.48 \pm 7.82$ & $* *$ \\
\hline チーズ & $249.99 \pm 17.71$ & $202.32 \pm 18.25$ & $*$ \\
\hline インスタントみそ汁 & $147.76 \pm 14.12$ & $94.40 \pm 8.84$ & $* *$ \\
\hline
\end{tabular}

一定期間後の学生の目測能力 · 食意識 · 食行動の变化 について, Amos16.0を用い, 回帰分析を行った。

\section{結果および考察}

\section{1. 対象者の生活環境}

表 2 に示した通り，居住形態は学生とその両親という 二世代が $75.9 \%$ 占めた。

\section{2. 目測誝差率}

目測誤差率を表 3 に示した。既報 ${ }^{5)}$ と同様に食品重量 は低く, 塩分含有量は高く見積もる傾向にあった。目測 誤差率が有意に改善されたのは26品目であった。逆に悪 化したのは，6品目であった。これは 1 年次の応用栄養 学・栄養指導総論などの講義で食品の目安量について学 習し，4月の段階では記憶に新しいが，12月では記憶が

表 3 B 2 回目に値に変化がなかった目測誤差率

\begin{tabular}{|c|c|c|c|}
\hline 食品名 & （4月） & （12月） & $\begin{array}{l}\text { Wil coxonの符 } \\
\text { 号つき順位検定 }\end{array}$ \\
\hline さば & $30.39 \pm 1.74$ & $27.68 \pm 1.93$ & n.s. \\
\hline 牛ステーキ & $57.27 \pm 3.87$ & $64.05 \pm 5.36$ & n.s. \\
\hline 鶏モモ肉 & $46.61 \pm 3.10$ & $43.47 \pm 3.22$ & n.s. \\
\hline スライスハム & $62.80 \pm 7.10$ & $72.20 \pm 9.11$ & n.s. \\
\hline チーズ & $52.16 \pm 3.68$ & $50.04 \pm 4.24$ & n.s. \\
\hline $\begin{array}{l}\text { シュークリーム } \\
\text { (調理食品) }\end{array}$ & $47.78 \pm 2.56$ & $56.96 \pm 5.02$ & n.s. \\
\hline おにぎり & $36.43 \pm 2.35$ & $43.49 \pm 2.81$ & n.s. \\
\hline キャベッ(せんぎり) & $56.32 \pm 4.51$ & $57.57 \pm 4.91$ & n.s. \\
\hline ほうれんそう (ゆで) & $53.72 \pm 4.32$ & $52.50 \pm 4.29$ & n.s. \\
\hline $\begin{array}{l}\text { 焼き魚 } \\
\text { (乾物・乾燥) }\end{array}$ & $40.53 \pm 2.84$ & $47.37 \pm 4.19$ & n.s. \\
\hline そうめん & $49.68 \pm 2.87$ & $45.38 \pm 3.61$ & n.s. \\
\hline 高野豆腐 & $81.19 \pm 7.49$ & $75.91 \pm 5.97$ & n.s. \\
\hline $\begin{array}{l}\text { しいたけ } \\
(\text { 乾物・戻したもの) }\end{array}$ & $101.01 \pm 8.70$ & $92.43 \pm 8.19$ & n.s. \\
\hline 高野豆腐 & $56.49 \pm 4.29$ & $54.63 \pm 4.00$ & n.s. \\
\hline ワカメ & $56.70 \pm 5.15$ & $64.36 \pm 12.05$ & n.s. \\
\hline しいたけ & $70.91 \pm 8.17$ & $59.91 \pm 5.68$ & n.s. \\
\hline $\begin{array}{l}\text { ひじき } \\
\text { (塩分) }\end{array}$ & $58.02 \pm 5.92$ & $99.55 \pm 29.45$ & n.s. \\
\hline $\begin{array}{l}\text { ロースハム } \\
\text { (糖分) }\end{array}$ & $287.32 \pm 22.72$ & $248.79 \pm 21.32$ & n.s. \\
\hline ポカリスウェット & $99.04 \pm 10.82$ & $108.03 \pm 17.93$ & n.s. \\
\hline 缶コーヒー & $94.88 \pm 9.08$ & $94.59 \pm 11.92$ & n.s. \\
\hline クッキー & $102.90 \pm 14.35$ & $92.75 \pm 10.63$ & n.s. \\
\hline 100\%果汁ジュース & $87.17 \pm 6.87$ & $70.89 \pm 4.30$ & n.s. \\
\hline 大福もち & $63.14 \pm 5.54$ & $64.49 \pm 5.90$ & n.s. \\
\hline
\end{tabular}

表 3 C 2 回目に值が悪化した目測誤差率

\begin{tabular}{|c|c|c|c|}
\hline 食品名 & (4月） & (12月） & 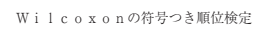 \\
\hline バナナ & $55.61 \pm 1.91$ & $85.00 \pm 46.56$ & $* * *$ \\
\hline ショートケーキ & $53.42 \pm 3.13$ & $88.69 \pm 7.05$ & $* * *$ \\
\hline クッキー & $74.06 \pm 5.77$ & $122.15 \pm 10.18$ & $* * *$ \\
\hline $\begin{array}{l}\text { トンカッ } \\
(\text { 乾物・戻したもの) }\end{array}$ & $57.53 \pm 4.74$ & $82.59 \pm 5.96$ & $* * *$ \\
\hline $\begin{array}{l}\text { 春雨 } \\
\text { (塩分) }\end{array}$ & $63.48 \pm 3.06$ & $64.01 \pm 11.82$ & $* *$ \\
\hline ケチャップ & $263.76 \pm 16.50$ & $272.34 \pm 39.63$ & $* * *$ \\
\hline
\end{tabular}


栄養士養成課程学生の目測能力および食意識変化

表 4 目測正解者率上位（20\%以上のもの）

\begin{tabular}{clcc}
\hline 順位 & 食品名 & \multicolumn{2}{c}{ 目測正解者率 $(\%)$} \\
\cline { 3 - 4 } & & 64.94 & 60.33 \\
1 & 鶏卵 & 44.44 & 16.20 \\
2 & 食パン & 37.34 & 17.17 \\
3 & ピーマン & 33.72 & 11.62 \\
4 & 白飯 & 27.74 & 11.29 \\
5 & 焼き魚 & 27.32 & 23.72 \\
6 & キャベッ（せんぎり） & 26.75 & 21.14 \\
7 & 油揚げ & 24.71 & 11.70 \\
8 & スライスハム & 21.96 & 10.05 \\
9 & ウインナー & 20.58 & 14.68 \\
10 & そうめん（乾） & 20.48 & 9.03 \\
11 & 鶏モモ肉 & & \\
\hline
\end{tabular}

薄らいだため，目測誤差率が悪化したと推測される。值 に変化がなかった食品の中で，塩分・糖分含有量は，目 に見えないものを推測する必要があるため難易度も高く, 正解者率も低值となった。これらの目測は各自の食品の 塩分・糖分についての知識量によって, 誤差率は左右さ れると推測される。また乾物などのように比重が小さく 軽いものは誤差率が大きくなりやすいことや, 戻したも のでもワカメ・ひじきなど少量のため重量把握が難し かったことも考えられる。さらにさば・牛ステーキ・鶏 モモ肉など形が一定しないものを目測することの難しさ も要因のひとつと思われる。また一定期間後 20 品目多く 改善された。今後, 改善された目測誤差率の食品数を増 加させ，さらに誤差率の值を降下させるため，目測調査 の結果を点数化し，個人の目測力を総合的に評価できる 方法を取り入れると, 学生の意識も変化し, 目測力向上 につながると思われる。

表 4 に正解者（目測誤差率10\%以内を適正に見積もら れた正解域群）率が高いものを示した。既報 ${ }^{5)}$ では，食 品では, 卵・食パン・ピーマンが, 調理食品では, おに ぎり・キャベツ（せんぎり）の正解者率が高かった。本 調査においても正解者率の高い食品は同様のものであっ た。卵・食パン・ピーマンは, 形が一定で目測しやすかっ たと推測される。表 3 B の 2 回目に值に変化がなかった 焼き魚・キャベッ (せん切り) ・ スライスハム・䳕モモ 肉は表 4 の目測正解者率では上昇しており，目測力にお いて学生間での差が大きく, 二極分化していると推測さ れる。

一定期間後の正解者率は高いものから, 卵・食パン・ ピーマン・白飯の順で，4月よりも正解者率は上昇した。 給食管理実習では，使用食材およびできあがった料理の 計量を行っている。また献立作成時には，フードモデル を使用して目測トレーニングを実施している。さらに市 販弁当の食材・調味料の目測と計測も行っているが，給 食管理実習での使用食材の出現率と正解者率の増加度に 相関関係がみられなかった $(\mathrm{R}=0.291, \quad \mathrm{P}=0.1)$ 。目測 能力の向上は, 給食管理実習 ·臨床栄養実習 · 栄養指導
論実習などの実習専門科目および栄養指導各論・臨床栄 養学などの講義専門科目の総合的な教育効果によって上 昇したことが推測される。

\section{3. 食意識・食生活行動調査}

表 5 に示した通り，一定期間後は，食事作り・買い物 頻度や值段の相場理解度は上昇し，レシピーを見ないで 何品作れるかなど調理能力は有意に上昇した $(\mathrm{p}<$ $0.001)$ 。また食生活管理能力 $(\mathrm{p}<0.001)$ も有意に上昇 し，目測自己評価は半数が向上したと思っていた。

一定期間前後における食意識・食生活行動を, 表 5 に 示した項目番号 1 ～24の項目について 1 ～5 点まで点数 化し平均值の差で比較すると，食意識・食生活行動はウ イルコクソン検定により有意に改善された（ $\mathrm{p}<0.001 ）$ （図 1 ）。

次に, 食意識・食生活行動調査の各項目および目測能 力において因子分析（主因子法）を行った。目測能力は, 目測誤差率において, 正解域 1 点, 正解域圈外 $=0$ 点と 点数化し, 表 1 の対象食品について各々合計点を求め, その合計点の平均值を求め, 4 月の結果の平均值を「目 測正解点 (4月)」12月の結果の平均值を「目測正解点 (12 月)」とした。「食材目測上達度」は，12月の目測誤差率 から 4 月の目測誤差率を差し引いた值の食品番号 $1 〜 26$ までの合計の平均値とした。同様に「調理食品目測上達 度」は食品番号27３3の平均值，「乾物目測上達度」は

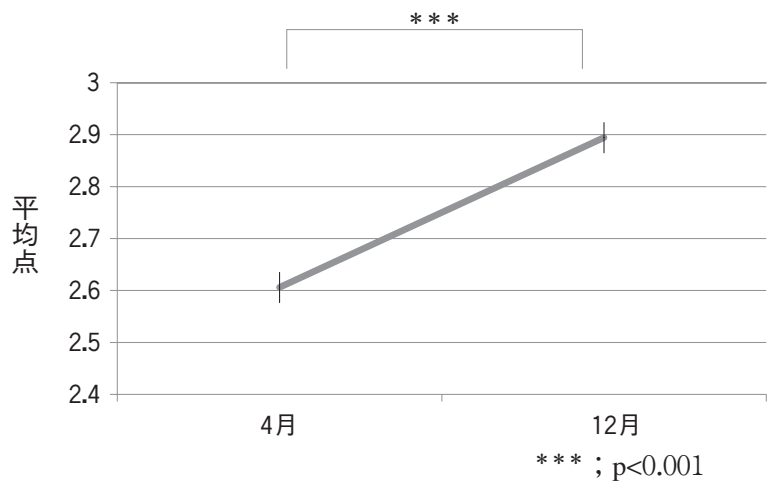

図 1 一定期間後の食意識・食生活行動の比較 
表 5 食意識・食生活行動

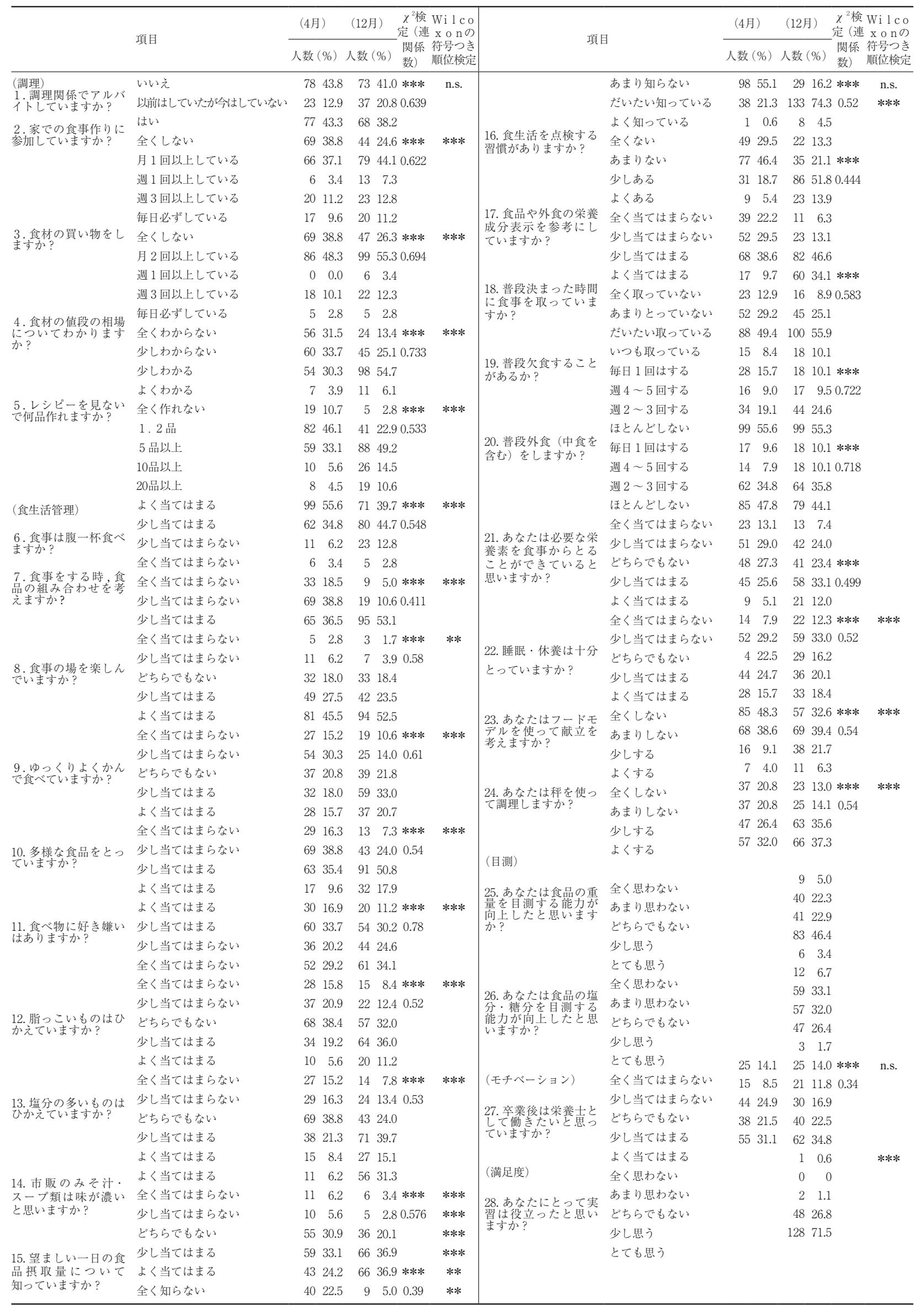

$* * * ; \mathrm{p}<0.001 \quad * * ; \mathrm{p}<0.01 \quad * ; \mathrm{p}<0.05$ 
食品番号34 45の平均值，「塩分含有量目測上達度」は 食品番号 $46 \sim 50$ の平均值, 「糖分含有量目測上達度」は 食品番号51～55の平均值とした。因子負荷量 0.350 以上 よりも低いものは削除し，因子分析を行ったところ，ス クリープロットがなだらかになるところより，5因子が 抽出された（表 6 )。

第 1 因子は「欠食・外食の有無」や「決った時間に食 事をとっているか」などで「規則正しい食事実践力」と 命名した。第 2 因子は「家での食事作りに参加している か」「レシピーをみないで何品作れるか」などで「調理 能力」と命名した。第 3 因子は，「好き嫌いがあるか」「多 様な食品をとっているか」で「バランスの良い食事実践 力」とし, 「食品重量の目測能力が向上したか」「塩分・ 糖分を目測する能力が向上したと思うか」で「目測自己 評価」とし，「バランスの良い食事・目測自己評価」と 命名した。第 4 因子は「目測正解点」「食材目測上達度」 で「目測能力」とし，「栄養士として働きたいか」で「モ チベーション」とし,「目測能力・モチベーション」と 命名した。第 5 因子は「ゆっくりよくかんで食べるか」 「腹いっぱい食べるか」で，「食べ過ぎ防止意識」と命名 した。この尺度の信頼性を検討するため Cronbach の $a$ 係数を求めたところ，第 1 因子は $\alpha=0.849$, 第 2 因子 は $\alpha=0.864$, 第 3 因子は $\alpha=0.790$, 第 4 因子は $\alpha=$ 0.741 ，第 5 因子は $\alpha=0.687$ であった。0.7以上で信頼 性が高いとみられることから，今回はまずまずの信頼性 であった。

栄養士養成課程学生の特性や能力として，「規則正し い食事実践力」調理能力」「バランスの良い食事実践力・
目測自己評価」「目測能力・モチベーション」「食べ過ぎ 防止意識」の 5 つの因子を持ち合わせていると考えられ る。これらの潜在変数で共分散構造分析を行ったが, モ デル図を描くことができなかった。そこで，一定期間後 の学生の目測能力, 食意識・食生活行動の変化について, 回帰分析を行い, パス図を図 2 に示した。

モデルの適合度 GFI は0.856, 修正適合度 AGFI は 0.791 と，モデル採択基準 ${ }^{6) 7} 0.9$ に近い值であった。平 均二乗誤差平方根 RESEA も0.050で，0.05以下とする 採択基準を示した。赤池情報量基準值 AIC は, 132.4で あった。 $\chi^{2}$ は76.4, 自由度 63 , 確率0.119であったため モデルの適合性は高いと考えられた。

4 月の時点での「卒業後栄養士として働きたいという 意欲」は「目測正解点 (4月)」に影響を与え, さらに「目 測正解点 (12月)」へとつながった。「秤を使って調理す ること（4月)」は，「目測正解点（4月）」に影響を与 えた。しかし「秤を使って調理すること（12月）」は，「目 測正解点（12月)」に直接影響を及ぼさなかった。「食材 の目測上達度」は「授業の満足度」につながった。12月 の時点での「卒業後栄養士として働きたいという意欲」 は「家で食事作りに参加しているか」「授業の満足度」 に影響を与えた（図 2 )。

次に目測上達度別に食意識・食生活行動についてまと め有意な関係にあった項目を表 7 に示した。食材料別お よび調理食品別目測が上達しているものは，「食事をす る時，食品の組み合わせを考える」ものの割合が多かっ た。乾物食品の目測が上達しているものは，「多様な食 品をとっている」,「塩分の多いものを控えている」，「必

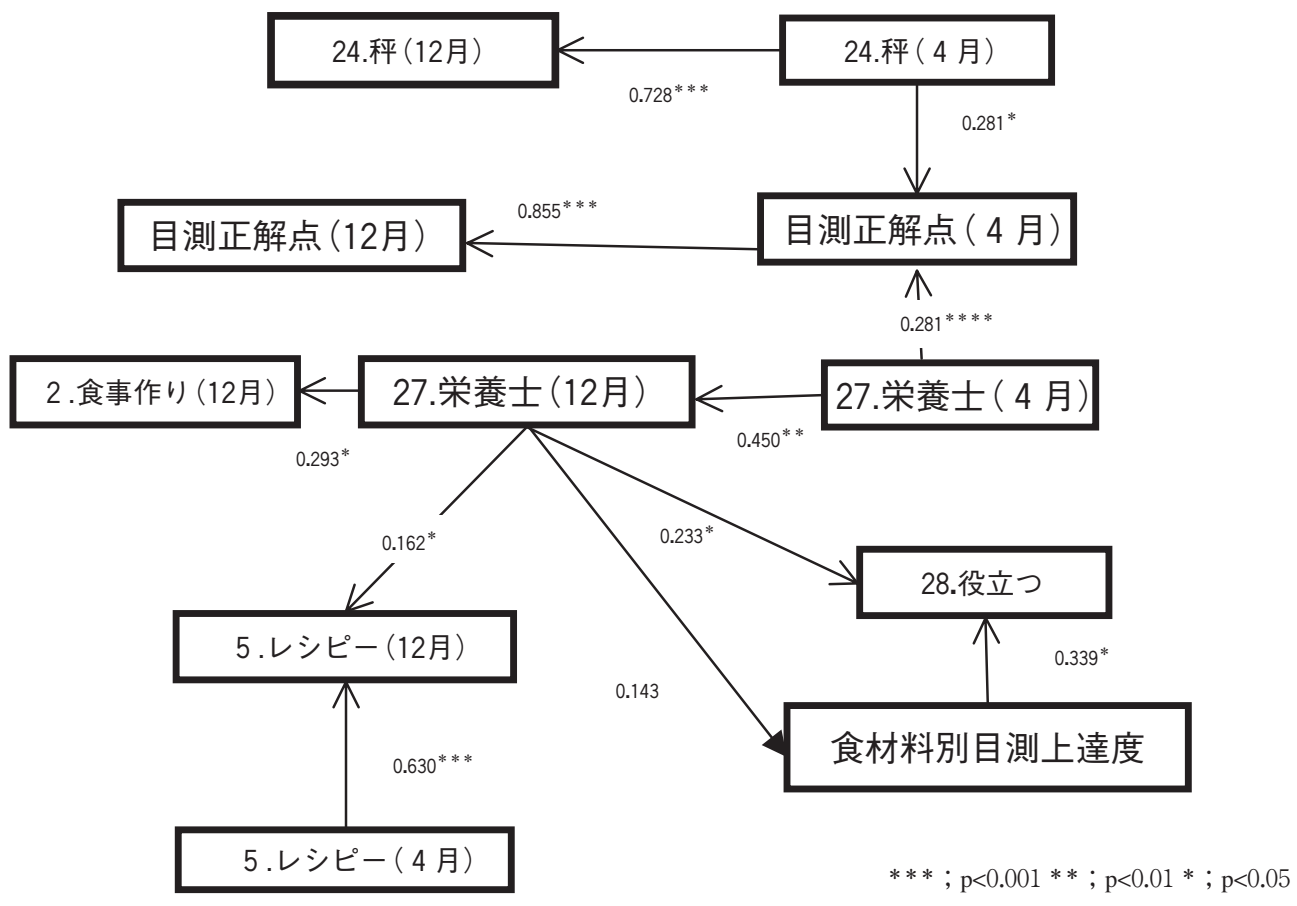

図 2 パス図

モデルの適合度 GFI；0.856，修正適合度 AGFI；0.791，平均二乗誤差平方根 RMSEA；0.05 赤池情報量基準 AIC; 132.4 
表 6 因子分析

\begin{tabular}{|c|c|c|c|c|c|}
\hline 項目 & 規則正しい食事実践力 & 調理能力 & $\begin{array}{l}\text { バランスの良い食事実 } \\
\text { 践力・目測自己評価 }\end{array}$ & $\begin{array}{l}\text { 目測能力・モ } \\
\text { チベーション }\end{array}$ & $\begin{array}{l}\text { 食べ過ぎ } \\
\text { 防止意識 }\end{array}$ \\
\hline 19. 欠食（12月） & 0.803 & -0.145 & 0.059 & 0.024 & -0.283 \\
\hline 19. 欠食（4月） & 0.767 & -0.101 & 0.047 & 0.076 & -0.211 \\
\hline 食行動平均点（12月） & 0.565 & 0.126 & 0.423 & 0.204 & 0.216 \\
\hline 22. 睡眠（12月） & 0.564 & -0.074 & -0.16 & -0.215 & 0.241 \\
\hline 18. 時間（12月） & 0.555 & 0.141 & -0.043 & 0.091 & -0.041 \\
\hline 21. 栄養素（12月） & 0.519 & 0.145 & 0.22 & -0.061 & -0.17 \\
\hline 22. 睡眠（4月） & 0.507 & -0.09 & -0.069 & -0.159 & 0.267 \\
\hline 14.スープ（12月） & -0.488 & 0.045 & 0.482 & 0.021 & -0.083 \\
\hline 21. 栄養素（4 月） & 0.465 & 0.183 & 0.156 & -0.163 & -0.106 \\
\hline 20. 外食（4月） & 0.46 & -0.018 & 0.105 & 0.207 & -0.178 \\
\hline 18. 時間（ 4 月） & 0.436 & 0.171 & -0.008 & 0.162 & 0.145 \\
\hline 20. 外食（12月） & 0.43 & -0.023 & 0.02 & 0.193 & -0.185 \\
\hline 食行動平均点 4 月 & 0.357 & 0.238 & 0.173 & 0.2 & 0.252 \\
\hline 5.レシピー（4月） & -0.236 & 0.757 & -0.076 & 0.138 & -0.079 \\
\hline 3.買い物（ 4 月） & 0.001 & 0.755 & -0.051 & -0.024 & 0.141 \\
\hline 2. 食事作り（4月） & 0.115 & 0.75 & -0.018 & 0.08 & -0.051 \\
\hline 2. 食事作り（12月） & 0.272 & 0.739 & -0.236 & 0.074 & 0.049 \\
\hline 3. 買い物（12月） & 0.176 & 0.684 & -0.239 & -0.089 & 0.314 \\
\hline 5.レシピー（12月） & -0.294 & 0.661 & -0.045 & 0.283 & 0.086 \\
\hline 4. 值段（4 月） & 0.042 & 0.644 & -0.049 & -0.169 & -0.161 \\
\hline 4. 值段（12月） & 0.104 & 0.476 & 0.135 & -0.192 & -0.117 \\
\hline 16. 点検（ 4 月） & -0.019 & 0.407 & 0.372 & -0.015 & -0.296 \\
\hline 15. 摂取量（4月） & -0.192 & 0.34 & 0.294 & 0.001 & 0.109 \\
\hline 12. 脂っこい（12月） & 0.117 & -0.166 & 0.696 & -0.14 & 0.305 \\
\hline 13. 塩分（12月） & 0.055 & -0.053 & 0.621 & 0.036 & 0.017 \\
\hline 13. 塩分（ 4 月） & 0.063 & 0.067 & 0.572 & 0.107 & -0.187 \\
\hline 25. 目測 ～～～～ & -0.085 & -0.107 & 0.57 & -0.029 & 0.235 \\
\hline 11. 好き嫌い（12月） & 0.098 & -0.24 & 0.504 & 0.112 & -0.011 \\
\hline 14.スープ（4月） & -0.324 & 0.195 & 0.477 & -0.132 & -0.177 \\
\hline 26. 塩目測 ～～～ & -0.241 & 0.074 & 0.47 & 0 & 0.381 \\
\hline 12. 脂っこい（4月） & 0.206 & 0.032 & 0.456 & -0.185 & 0.146 \\
\hline 11. 好き嫌い（ 4 月） & 0.13 & -0.229 & 0.436 & 0.126 & 0.014 \\
\hline 7.組み合わせ（12月） & 0.142 & 0.137 & 0.368 & 0.057 & 0.149 \\
\hline 10.多様（12月） & 0.155 & 0.166 & 0.365 & -0.203 & -0.055 \\
\hline 10.多様（4月） & 0.246 & 0.261 & 0.351 & -0.24 & -0.154 \\
\hline 15. 摂取量（12月） & -0.14 & 0.056 & 0.328 & 0.256 & 0.056 \\
\hline 目測過大小平均前 & 0.08 & 0.055 & -0.091 & 0.727 & -0.05 \\
\hline 目測過大小平均後 & 0.082 & 0.103 & -0.144 & 0.645 & -0.064 \\
\hline 28. 役立つ & 0.118 & -0.264 & 0.042 & 0.639 & -0.039 \\
\hline 食材別目測上達度 & -0.048 & -0.029 & -0.048 & 0.415 & 0.142 \\
\hline 17. 栄養成分表示（12月） & 0.07 & -0.047 & 0.207 & 0.403 & 0.045 \\
\hline 24. 秤（12月） & -0.017 & 0.055 & 0.257 & 0.379 & 0.109 \\
\hline 27. 栄養士（12月） & 0.252 & 0.137 & -0.072 & 0.374 & -0.085 \\
\hline 27. 栄養士（4月） & 0.359 & -0.065 & 0.048 & 0.37 & 0.023 \\
\hline 24. 秤（4月） & -0.13 & 0.099 & 0.118 & 0.326 & 0.084 \\
\hline 9.ゆっくりかむ（12月） & -0.129 & -0.078 & 0.195 & 0.093 & 0.656 \\
\hline 9.ゆっくりかむ（4月） & -0.092 & -0.065 & 0.273 & 0.053 & 0.612 \\
\hline 6. 腹一杯 (4月) & -0.147 & -0.036 & 0.081 & 0.051 & 0.526 \\
\hline 6. 腹一杯（12月） & -0.005 & 0.154 & -0.126 & -0.114 & 0.421 \\
\hline \multicolumn{6}{|l|}{ 相関係数 } \\
\hline 規則正しい食事実践力 & 1 & 0.261 & 0.104 & 0.062 & 0.1 \\
\hline 調理能力 & 0.261 & 1 & 0.366 & 0.168 & 0.021 \\
\hline $\begin{array}{l}\text { バランスの良い食事実践 } \\
\text { 力・目測自己評価 }\end{array}$ & 0.104 & 0.366 & 1 & 0.206 & 0.002 \\
\hline 目測能力・モチベーション & 0.062 & 0.168 & 0.206 & 1 & 0.098 \\
\hline 食べ過ぎ防止意識 & 0.1 & 0.021 & 0.002 & 0.098 & 1 \\
\hline$a$ 係数 & 0.849 & 0.864 & 0.79 & 0.741 & 0.687 \\
\hline
\end{tabular}


栄養士養成課程学生の目測能力および食意識変化

表7 目測上達度別食意識・食生活行動

\begin{tabular}{|c|c|c|c|c|c|c|c|c|}
\hline \multirow{3}{*}{ 項目 } & & \multirow{3}{*}{$\begin{array}{l}\text { 目測 } \\
\text { 品目 }\end{array}$} & \multicolumn{4}{|c|}{ 目測上達有無 } & \multirow{3}{*}{$\begin{array}{c}\chi^{2} \text { 検定 } \\
\text { (連関係数) }\end{array}$} & \multirow{3}{*}{$\begin{array}{c}\text { Mann- } \\
\text { WhitneyU } \\
\text { 検定 }\end{array}$} \\
\hline & & & \multicolumn{2}{|c|}{ 有 } & \multicolumn{2}{|c|}{ 無 } & & \\
\hline & & & 人数 & $(\%)$ & 人数 & $(\%)$ & & \\
\hline $\begin{array}{l}7 . \text { 食事をする時, 食品 } \\
\text { の組み合わせを考えます } \\
\text { か? (12月) }\end{array}$ & $\begin{array}{l}\text { 全く当てはまらない } \\
\text { 少し当てはまらない } \\
\text { 少し当てはまる } \\
\text { よく当てはまる }\end{array}$ & $\begin{array}{l}\text { 食 } \\
\text { 材 } \\
\text { 料 } \\
\text { 別 }\end{array}$ & $\begin{array}{r}6 \\
10 \\
79 \\
43\end{array}$ & $\begin{array}{r}4.3 \\
7.2 \\
57.2 \\
31.2\end{array}$ & $\begin{array}{r}3 \\
9 \\
14 \\
10\end{array}$ & $\begin{array}{l}8.3 \\
25 \\
38.9 \\
27.8\end{array}$ & $\begin{array}{l}* \\
0.012\end{array}$ & n.s. \\
\hline $\begin{array}{l}\text { 7. 食事をする時, 食品 } \\
\text { の組み合わせを考えます } \\
\text { か? (12月) }\end{array}$ & $\begin{array}{l}\text { 全く当てはまらない } \\
\text { 少し当てはまらない } \\
\text { 少し当てはまる } \\
\text { よく当てはまる }\end{array}$ & $\begin{array}{l}\text { 調 } \\
\text { 瑆 } \\
\text { 㗊 } \\
\text { 別 }\end{array}$ & $\begin{array}{r}3 \\
7 \\
67 \\
35\end{array}$ & $\begin{array}{r}2.7 \\
6.3 \\
59.8 \\
31.3\end{array}$ & $\begin{array}{r}6 \\
12 \\
26 \\
18\end{array}$ & $\begin{array}{r}9.7 \\
19.4 \\
41.9 \\
29.0\end{array}$ & $\begin{array}{l}* * \\
0.006\end{array}$ & n.s. \\
\hline $\begin{array}{l}\text { 10. 多様な食品をとって } \\
\text { いますか（12月） }\end{array}$ & $\begin{array}{l}\text { 全く当てはまらない } \\
\text { 少し当てはまらない } \\
\text { 少し当てはまる } \\
\text { よく当てはまる }\end{array}$ & $\begin{array}{l}\text { 榦 } \\
\text { 物 }\end{array}$ & $\begin{array}{r}4 \\
20 \\
58 \\
19\end{array}$ & $\begin{array}{r}4.0 \\
19.8 \\
57.4 \\
18.8\end{array}$ & $\begin{array}{r}9 \\
21 \\
29 \\
13\end{array}$ & $\begin{array}{l}12.5 \\
29.2 \\
40.3 \\
18.1\end{array}$ & * 0.040 & $*$ \\
\hline $\begin{array}{l}\text { 13. 塩分の多いものはひ } \\
\text { かえていますか? (12 } \\
\text { 月) }\end{array}$ & $\begin{array}{l}\text { 全く当てはまらない } \\
\text { 少し当てはまらない } \\
\text { どちらでもない } \\
\text { 少し当てはまる } \\
\text { よく当てはまる }\end{array}$ & $\begin{array}{l}\text { 乾 } \\
\text { 物 }\end{array}$ & $\begin{array}{r}9 \\
19 \\
17 \\
42 \\
14\end{array}$ & $\begin{array}{r}8.9 \\
18.8 \\
16.8 \\
41.6 \\
13.9\end{array}$ & $\begin{array}{r}5 \\
4 \\
25 \\
25 \\
10\end{array}$ & $\begin{array}{r}7.2 \\
5.8 \\
36.2 \\
36.2 \\
14.5\end{array}$ & $\begin{array}{l}* \\
0.020\end{array}$ & n.s. \\
\hline $\begin{array}{l}\text { 20. 普段外食（中食を含 } \\
\text { む）をしますか（4月） }\end{array}$ & $\begin{array}{l}\text { 毎日 } 1 \text { 回はする } \\
\text { 週 } 4 \text { 〜 回する } \\
\text { 週 } 2 \text { 〜 } 3 \text { 回する } \\
\text { ほとんどしない }\end{array}$ & $\begin{array}{l}\text { 塩 } \\
\text { 足 }\end{array}$ & $\begin{array}{r}5 \\
11 \\
34 \\
50\end{array}$ & $\begin{array}{r}5.0 \\
11.0 \\
34.0 \\
50.0\end{array}$ & $\begin{array}{r}11 \\
3 \\
26 \\
29\end{array}$ & $\begin{array}{r}7.4 \\
15.9 \\
4.3 \\
37.7\end{array}$ & $\begin{array}{l}* \\
0.048\end{array}$ & n.s. \\
\hline $\begin{array}{l}\text { 21. あなたは必要な栄養 } \\
\text { 素を食事からとることが } \\
\text { できていると思います } \\
\text { か？(4月) }\end{array}$ & $\begin{array}{l}\text { 全く当てはまらない } \\
\text { 少し当てはまらない } \\
\text { どちらでもない } \\
\text { 少し当てはまる } \\
\text { よく当てはまる }\end{array}$ & $\begin{array}{l}\text { 乾 } \\
\text { 物 }\end{array}$ & $\begin{array}{r}5 \\
24 \\
31 \\
39 \\
11\end{array}$ & $\begin{array}{r}4.5 \\
21.8 \\
28.2 \\
35.5 \\
10.0\end{array}$ & $\begin{array}{r}8 \\
17 \\
9 \\
16 \\
10\end{array}$ & $\begin{array}{l}13.3 \\
28.3 \\
15.0 \\
26.7 \\
16.7\end{array}$ & $\begin{array}{l}* \\
0.044\end{array}$ & n.s. \\
\hline
\end{tabular}

要な栄養素を食事からとることができている」ものの割 合が多かった。塩分濃度の目測が上達しているものは, 「普段外食をする」ものの割合は少なかった。したがっ て目測能力の向上には，秤を使って調理するという実践 的演習だけではなく，「食事をする時，食品の組み合わ せを考える」という「バランスのよい食事実践力」が重 要であることが示唆された。

また海藻の摂取量は女子大生は少ないと報告されてい る ${ }^{8)}$ が, 海藻は乾物のものが多く, 乾物の目測能力の向 上には，まずは海藻などの乾物の摂取量をあげることも 重要になってくると推測される。そのためには,「必要 な栄養素を食事からとることができる」という「規則正 しい食事実践力」と，「多様な食品をとっている」およ び「塩分の多いものを控えている」という「バランスの よい食事実践力」を身につけ，乾物摂取の必要性を各個 人が認識することが大切であることが推測される。

塩分濃度の目測能力の向上には，「外食は控える」こ とがなぜ必要かという知識を身につけることも大切であ
ると思われる。

したがって栄養士スキルの向上には, 授業において「規 則正しい食事」「バランスのよい食事」がなぜ重要かと いう科学的根拠を明らかにし, 学生がその実践力を体得 することが必要となる。

また，実習開始前に学生のモチベーションをいかに上 昇させるかが, 鍵となってくることも明らかとなった。 今後の検討課題といえる。さらに「授業の満足度」を上 昇させるために，学生のウォンツおよびニーズを，アン ケートなどで情報収集を行い，授業内容をさらに充実さ せるため，検討を重ねることが重要であると考えられる。

\section{要 約}

栄養士を志す女子学生の食品重量や塩分・糖分濃度の 目測能力および食意識が一定期間専門科目の教育を受け た後, どのように変化したかについて調べた。さらに教 育効果を向上させるために必要な項目について検討した。 (1) 一定期間後, 目測誤差率は, 目測誤差率が有意に改 
善されたのは26品目であった。逆に悪化したのは， 6 品目であった。一定期間後 20 品目多く改善された。

(2) 一定期間後は, 調理能力・食生活管理能力は有意に 上昇した。目測自己評価は半数が向上したと思ってい た。また食意識・食生活行動も有意に改善された。

(3) 食意識・食生活行動調查の各項目および目測能力の 因子分析より，栄養士養成課程学生の特性や能力とし て,「規則正しい食事実践力」「調理能力」「バランス の良い食事実践力・目測自己評価」「目測能力・モ千 ベーション」「食ベ過ざ防止意識」の 5 つの因子を持 ち合わせていると考えられた。

（4）目測能力の向上には，秤を使って調理するという実 践的演習だけではなく、「規則正しい食事実践力」「バ ランスのよい食事実践力」が重要であることが示唆さ れた。

（5）栄養士スキルの向上には，授業に扔いて「規則正し い食事」「バランスのよい食事」がなぜ重要かという 科学的根拠を明らかにし，学生がその実践力を体得す ることが必要である。

（6）実習開始前に学生のモチベーションをいかに上昇さ せるかが，鍵となってくることが明らかとなった。

\section{引用文献}

1）黑川由美, 青木洋子, 永野君子：給食管理実習に打辇る 献立構成要素，帝塚山短期大学部紀要，40，9（2003）

2）相田理恵, 渡辺早苗, 穴倉弘江, 佐藤智英, 西村薰子： 糖尿病患者に扔ける食品のエネルギー見積もり能力, 栄養 学雑誌, 54, 97-108 (1996)

3 ）健康·栄養情報研究会編: 平成12年厚生労働省国民栄調 查結果，第一出版，122（2002）

4）照井真紀子，鈴木久乃：ある栄養士課程に打ける学生の 献立作成能力の要因, 栄養学雑誌, 58, 77-84 (2000)

5）堀内理恵, 福田 滿：給食管理実習に扔ける学生の献立 形成能力の実態, 大阪夕陽丘学園短期大学紀要, 49, 29-34 (2005)

6）松本晴美, 深澤早苗: 家庭の食生活環境と学校の給食調 理方式が中学生の食意識・食行動, 給食に対する評価抢上 び健康状態に及ぼす影響, 日本家政学会誌, 58, 681-692(2007)

7) 小塩真司：SPSS とAmosによる心理・調查データ一解析, 東京書籍, 180-182 (2007)

8）古橋優子, 八木明彦, 酒井映子：女子学生の料理レベル からみた食生活状況との関連，日本食生活学会誌，17，130 -140 (2006) 